\title{
La resurrección de Jesús, esperanza para los pueblos crucificados Aproximación desde la Biblia y la teología contemporánea
}

\section{Xavier Alegre,}

Centro de Reflexión Teológica, San Salvador,

Facultad de Teología de Cataluña, Barcelona.

\section{Introducción. ¡Amenazados de resurrección!}

Quisiera empezar con un texto que me parece muy iluminador y que expresa bien por qué la resurrección de Jesús es fuente de esperanza para los pueblos crucificados. Es atribuido a un periodista guatemalteco:

Dicen que estoy "amenazado de muerte"... Tal vez. Sea ello lo que fuere, estoy tranquilo. Porque si me matan, no me quitarán la vida. Me la llevaré conmigo, colgando sobre el hombro, como un morral de pastor...

A quien se mata se le puede quitar todo previamente, tal como se usa hoy, dicen: los dedos de las manos, la lengua, la cabeza... Se le puede quemar el cuerpo con cigarrillos, se le puede aserrar, partir, destrozar, hacer picadillo... Todo se le puede hacer, y quienes me lean se conmoverán profundamente y con razón.

Yo no me conmuevo gran cosa. Porque, desde niño, Alguien sopló a mis oídos una verdad inconmovible que es, al mismo tiempo, una invitación a la eternidad: "No temáis a los que pueden matar el cuerpo, pero no pueden quitar la Vida". La vida - la verdadera vida - se ha fortalecido en mí cuando, a través de Pierre Teilhard de Chardin, aprendí a leer el Evangelio: el proceso de la Resurrección empieza con la primera arruga que nos sale en la cara; con la primera mancha de vejez que aparece en nuestras manos; con la primera cana que sorprendemos en nuestra cabeza un día cualquiera, peinán- 
donos; con el primer suspiro de nostalgia por un mundo que se deslíe y se aleja, de pronto, frente a nuestros ojos...

Así empieza la resurrección. Así empieza no eso tan incierto que algunos llaman "la otra vida", pero que en realidad no es la "otra vida", sino la vida "otra"...

Dicen que estoy amenazado de muerte... De muerte corporal a la que amó Francisco. ¿Quién no está "amenazado de muerte"? Lo estamos todos desde que nacemos. Porque nacer es un poco sepultarse también...

Amenazados de muerte. ¿Y qué? Si así fuere, los perdono anticipadamente. Que mi cruz sea una perfecta geometría de amor, desde la que pueda seguir amando, hablando, escribiendo y haciendo sonreír, de vez en cuando, a todos mis hermanos los hombres.

Que estoy amenazado de muerte... Hay en la advertencia un error conceptual. Ni yo ni nadie estamos amenazados de muerte. Estamos amenazados de vida, amenazados de esperanza, amenazados de amor...

Estamos equivocados. Los cristianos no estamos amenazados de muerte. Estamos "amenazados" de resurrección. Porque además del Camino y de la Verdad, él es la Vida, aunque esté crucificada en la cumbre del basurero del Mundo...

Pienso que es también la fe en la resurrección de Jesús la que llevó a Mons. Romero a no temer la muerte y a exclamar, poco antes de que fuera asesinado:

He sido frecuentemente amenazado de muerte. Debo decirle que como cristiano no creo en la muerte sin resurrección; si me matan, resucitaré en el pueblo salvadoreño. Se lo digo sin ninguna jactancia, con la más grande humildad.

Como pastor estoy obligado por mandato divino a dar la vida por quienes amo, que son todos los salvadoreños; aun por aquellos que vayan a asesinarme. Si llegaran a cumplirse las amenazas, desde ya ofrezco a Dios mi sangre por la redención y resurrección de El Salvador.

El martirio es una gracia que no creo merecer, pero si Dios acepta el sacrificio de mi vida, que mi sangre sea semilla de libertad y la señal de que la esperanza será pronto una realidad.

Mi muerte, si es aceptada por Dios, sea por la liberación de mi pueblo y como un testimonio de esperanza en el futuro. Puede decir usted, si 1legasen a matarme, que perdono y bendigo a quienes lo hagan.

Ojalá, sí, se convenzan de que perderán su tiempo. Un obispo morirá, pero la Iglesia de Dios, que es el pueblo, no perecerá jamás... 
Por la fe que transparentan estos textos, los cristianos que acabo de mencionar están en la auténtica sintonía con Jesús de Nazaret, ya que, según los evangelios, Jesús mismo habló de su muerte próxima dentro del horizonte de su resurrección ( $c f r$. Mc 8,$31 ; 9,31 ; 10,32-34$ ). Y se enfrentó libremente a ella por amor a la humanidad y por amor a Dios y al proyecto que Dios le había confiado. Un proyecto que él, con la tradición del Antiguo Testamento, denominaba el "reinado de Dios", un mundo en el que reinara la paz con justicia y la solidaridad universal.

Y, a la vez, a medida que fue profundizándose cristológicamente la comprensión de la persona de Jesús y las implicaciones de la fe en su resurrección, se fue formulando cada vez más claramente hasta qué punto era Dios, de modo que en Juan ya no se confiesa simplemente que Dios le resucitó, sino que Jesús dice de sí mismo que él tiene poder para entregar la vida y para resucitar (cfr. 10,17-18).

La fe en la resurrección de los muertos, sin embargo, es una verdad controvertida. ¿Por qué resulta hoy tan difícil para muchos creer en la resurrección de los muertos? J. A. Pagola señala bien una de las razones cuando escribe:

Configurados por una cultura que valora de manera predominante los "fenómenos observables", nos resulta difícil sintonizar con aquello que no podemos reducir a dato controlable. Entonces hablamos de la Resurrección de Jesús como desde fuera. Tratamos de iluminarla desde el exterior. Estudiamos el sepulcro vacío, las apariciones del Resucitado, el testimonio de los discípulos, pero no acertamos a vivir nosotros mismos "la experiencia pascual".

Pero hay también otra razón que es consecuencia de que a veces no hemos comprendido, ni explicado bien, lo que significa la Resurrección de los muertos para la fe cristiana. A algunos autores la fe en la resurrección de los muertos (y de Jesús) les parece alienante, deshumanizante. Así lo indica, por ejemplo, Lucio Lombardo-Radice ${ }^{2}$. Según este autor, una afirmación como la de Pablo en 1 Co 15,12 ss, implica que los cristianos no son unos buenos humanistas, porque afirman que, si después de la muerte no existe otra vida, nuestra aventura humana en este mundo no tiene sentido. Y se rebela contra esta afirmación. Pues se hace las siguientes preguntas: ¿No tiene sentido en sí mismo el amor que me une a mi esposa? ¿No son mis hijos una experiencia permanente de sentido? ¿Negará alguien que con mi trabajo preparo días mejores para la humanidad futura? ¿Es posible que se niegue consistencia a los 65 ó 70 años que puedo vivir en esta tierra? ¿Por qué vamos a extender por el mundo el rumor de que, si todo acaba

1. J. A. Pagola, Creer en el Resucitado. Esperar en nuestra resurrección, Santander: Editorial Sal Terrae, 1991, p. 33.

2. Citado por M. Fraijó, "La resurrección de Jesús, fundamento de la fe", en Jesús y los marginados. Utopia y esperanza cristiana, Madrid: Ediciones Cristiandad, 1985, p. 232. 
con la muerte, somos unos desgraciados? ¿No implica, entonces, predicar esta fe en la resurrección de los muertos un humanismo pobre, si es que se le puede calificar de humanista?

De hecho, incluso santos como san Juan María Vianney se rebelaban contra una concepción de la resurrección de los muertos que implicara una devaluación de esta vida. Por eso decía que, si al morir llegara a constatar que no había nada después de esta vida, le habrían engañado; pero habría valido la pena haber vivido como había vivido.

Pero como vamos a ver a través de los testimonios bíblicos sobre la resurrección de Jesús (y de los muertos: ¡Jesús es su primicia!), solo una concepción equivocada de la fe en la otra vida y en la resurrección de Jesús puede llevar a no valorar este mundo y a dejar de luchar para que sea mejor. Es lo que indica bien Pagola ${ }^{3}$ :

Precisamente porque cree y espera un mundo nuevo y definitivo, el creyente no puede tolerar ni conformarse con este mundo tal como hoy es, lleno de odios, lágrimas, injusticia, mentira y violencia. Quien no hace nada por cambiar este mundo no cree en otro mejor. Quien no lucha contra la injusticia no quiere "unos cielos nuevos y una nueva tierra donde habite la justicia" (1 Pe $3,13)$. Quien no trabaja por liberar al hombre del sufrimiento no cree en un mundo nuevo y feliz. Quien no hace nada por cambiar y transformar esta tierra no cree en el cielo.

De todos modos no debería sorprendernos que la fe en la resurrección de Jesús cree hoy dificultades. Pues, de hecho, la fe en la resurrección de los muertos es algo que ya creó dificultades a algunos cristianos de Corinto, provocando que Pablo llegara a afirmar que, si los muertos no resucitan, entonces tampoco Cristo ha resucitado. Y ello implicaría que nuestra fe es vana, que no tiene fundamento $(c f r .1 \text { Co } 15,12 \mathrm{ss})^{4}$. Pero ello sólo es verdad, y una aportación cristiana al

3. J. A. Pagola, óp. cit, pp. 31 y s. Ya D. Bonhoeffer, Resistencia y sumisión, Barcelona, 1971, p. 198, había insistido en este aspecto: "Ahora se dice que lo decisivo es que el cristianismo proclamó la esperanza en la resurrección y que así originó una auténtica religión de la redención. El centro de gravedad se halla, pues, más allá de la muerte. Ahí, precisamente, es donde yo veo el error y el peligro. Pues, entonces, redención quiere decir liberación de las preocupaciones, de los peligros, de las angustias y deseos, del pecado y la muerte en un más allá mejor. Pero, ¿realmente es éste el elemento esencial de la revelación de Cristo según los Evangelios y San Pablo? Yo lo niego. La esperanza cristiana en la resurrección se diferencia de la esperanza mitológica por el hecho de que remite al hombre, de un modo totalmente nuevo y aún más tajante que en el Antiguo Testamento, a su vida en la tierra.

4. De hecho, y para subrayar la importancia de la resurrección de Jesús, T. Lorenzen empieza así su libro Resurrección y discipulado, Santander, 1999, p. 15: "Cuando hablamos de la resurrección de Jesucristo no tratamos una cuestión de fe, sino la cues- 
diálogo con las otras religiones y las personas no creyentes de buena voluntad, cuando se entiende bien qué es lo que quiere decir el Nuevo Testamento cuando habla de la resurrección de Jesús y de los muertos.

Teniendo, pues, en cuenta lo que acabo de decir, dos son los aspectos, interrelacionados, que quiero tratar aquí en mi reflexión: 1) ¿Qué podemos saber y decir hoy sobre la resurrección de Jesús?, y 2) ¿Por qué dicha resurrección es fuente de esperanza para los pueblos crucificados?, un aspecto que solo podremos responder al llegar al final de nuestra reflexión.

\section{1. ¿Qué podemos saber hoy sobre la resurrección de Jesús?}

Mi punto de referencia fundamental serán los textos bíblicos. Como señala muy bien J. Sobrino ${ }^{5}$, podemos acercarnos a dichos textos desde tres puntos de mira, en principio, complementarios. Nos podemos plantear

1) la cuestión histórica: ¿Qué les ocurrió a los primeros testigos de la resurrección, qué experimentaron, sintieron, "vieron"?

2) la cuestión hermenéutica: ¿Qué quieren decir(nos) los textos bíblicos? Para ello tendremos que estudiar las formas literarias que se utilizan, las implicaciones culturales de los textos, teniendo en cuenta que, en principio, la resurrección de Jesús, tal como está testimoniada en el Nuevo Testamento, no es un mero retorno a esta vida temporal, sino algo "escatológico", definitivo, el principio de una nueva creación ( $c f r$. Ap 21,1-5), prometida por Dios para el fin de los tiempos. Nos encontraremos, por tanto, como veremos, con lo que se ha denominado "una barrera del lenguaje".

3) la cuestión teológica: ¿Qué significa —en los inicios de la Iglesia y hoyla confesión creyente de que Cristo ha resucitado? Como sabemos, no se trata solo de algo que sucedió puntualmente en el pasado. Más bien, es

tión de la fe cristiana. La resurrección no es solo un objeto de fe, ni es simplemente una afirmación del credo que se ha de aceptar; es el origen y fundamento de la fe. En ella se decide la naturaleza y el contenido de la fe, lo que la fe cristiana es en realidad. No es un mero problema histórico: nos vemos enfrentados a la difícil tarea de dilucidar lo que es la historia como tal. No nos ocupamos simplemente de uno de los actos de Dios en la historia: nos encontramos frente a la naturaleza misma de Dios y al modo en que se relaciona con nosotros y con su creación". Y H. Kessler, La resurrección de Jesús. Aspecto bíblico, teológico y sistemático, Salamanca: Ediciones Sígueme, 1989, p. 11, señala: "La resurrección de Jesucristo constituye un tema clave, quizá el tema clave de la fe cristiana. De ella depende la respuesta en casi todas las cuestiones de la fe y de la teología".

5. J. Sobrino, La fe en Jesucristo. Ensayo desde las víctimas, Madrid: Trotta Editorial, 1999 , p. 33-166. 
la inauguración de una vida y de un mundo nuevo que ha empezado con Jesús y del cual participamos ya por la fe vivida en comunidad, por la eucaristía, etc. Se trata, pues, de algo que me afecta personalmente.

De entrada, hemos de ser conscientes de que no tenemos acceso directo a la cuestión histórica. Ni estábamos allí cuando los primeros testigos de la resurrección hicieron la experiencia, ni podemos hablar con ninguno de ellos. Por ello partiremos de los textos biblicos que dan testimonio de la resurrección, supuesto que ellos son el fundamento de nuestra fe y creemos que están inspirados por Dios. Es a partir de estos textos, y de su interpretación, como nos podremos preguntar qué debió ocurrir hacia los años 30, a los inicios de la Iglesia. Solo entonces podemos comprender mejor qué debió significar entonces, y qué puede significar ahora para nosotros, la fe en la resurrección de Jesús.

\section{Cuestión previa fundamental: ¿qué queremos decir cuando confesamos que Dios resucitó a Jesús?}

Lo primero que quiero destacar es que, para los primeros cristianos, predicar la resurrección de Jesús les llevó a entrar en conflicto con las autoridades civiles y religiosas de su mundo ( $c f r$. Hch 4,1-3; 5,29-33; 7,56-58; también lo indica Pablo en Hch 23,$6 ; 24,1$ ). Por ello nos hemos de preguntar, ante todo, por qué, a los inicios de la Iglesia, confesar la resurrección de Jesús resultaba conflictivo, mientras que ahora les parece a muchos un tema alienante $\mathrm{y}$, en todo caso, nada conflictivo políticamente.

La razón principal se encuentra en el hecho de que, en la cultura de aquella época, afirmar que Dios había resucitado a Jesús significaba que Dios había dado la razón precisamente al Crucificado, al rechazado por las autoridades políticas y religiosas de Judea y que, por tanto, la víctima había triunfado — en el juicio de Dios - sobre sus verdugos.

Por eso resultaba tan conflictivo anunciar que Dios había resucitado a Jesús. Pues los que habían condenado a muerte a Jesús seguían siendo los poderosos en el mundo de las primeras comunidades cristianas.

Por otro lado, si confesar la resurrección de Jesús significaba profesar que Je sús había tenido razón en su vida, en su modo de vivir y actuar, entonces podemos comprender mejor por qué los primeros testigos de la resurrección, más que contar el contenido de sus visiones o experiencias pascuales con ayuda de unas revelaciones "esotéricas", que habrían recibido en la intimidad de su vida, lo que hacen es explicar la vida concreta de Jesús de Nazaret. Porque ésta es la vida que le llevó a la cruz y, consecuentemente, a la resurrección. Como muestra muy bien Marcos (y los otros evangelistas siguen su ejemplo), para hablar del Resucitado lo que hacen es recuperar su vida, una vida que le llevó a la Resurrección a través de la cruz. 
En este sentido, el arzobispo y teólogo K. Lehmann hace el siguiente comentario:

Nada se nos ofrece que sea parecido a lo que los hombres esperan de alguien que volviera de la muerte. Nada se nos cuenta que contribuya a una mejor comprensión o aclaración de la catástrofe de la Cruz. Ni una sola palabra que pueda satisfacer la curiosidad de lo que pasa en la "otra vida". Los profetas de otras religiones revelan en tales circunstancias todo el esplendor y la magnificencia del cielo, las mitologías se multiplican. Nada de eso se nos cuenta en los Evangelios. No hay referencia alguna al acontecimiento de la Resurrección misma, que queda escondido en Dios. Lo único que se desvela de este acontecimiento emerge en lo que se manifiesta en las apariciones. Ellas son las que atestiguan el poder de la Resurrección tal y como se actualiza en la historia del mundo y de los hombres. El acontecimiento de la Resurrección y las apariciones están indisolublemente unidos, pero no constituyen una realidad única. Las apariciones y el testimonio de la gloria absolutamente escondida de Dios, cuyo misterio acontece en la Resurrección, son el "paso" al mundo histórico espacio-temporal. En este proceso realizado dentro de nuestra historia, se anuncia lo que opera y significa para nosotros la Resurrección. ${ }^{6}$

Por eso ahora, a partir de Pascua, los discípulos no hablan de revelaciones especiales, secretas, que les hubiera hecho el Resucitado, sino que cuentan lo que Jesús hizo y dijo durante su vida terrena, pero explicado desde la luz que sobre esta vida proyecta la experiencia pascual. Y desde el trasfondo del Antiguo Testamento, que se convierte ahora en clave de lectura y de comprensión creyente, tanto de la vida de Jesús, como sobre todo del escándalo de su pasión y cruz (cfr. Lc 24,25-27.44-45).

Una buena muestra de cómo los primeros cristianos comprendieron la resurrección de Jesús, en conexión con la Cruz de una víctima inocente, la encontramos en Marcos. El primer evangelista es muy consciente de que la muerte de Jesús no fue provocada por alguna enseñanza blasfema (el lector de Mc 14,5564 sabe que la acusación del Sumo sacerdote es falsa). O por ser un terrorista (aunque los romanos lo crucificaron como si fuera un terrorista, para difamarle: cfr. Mc 15,1,15.26-27). Se trata de una suposición falsa y Jesús se defiende de ella ante los que van a Getsemaní a prenderle (cfr. Mc 14,48-49).

No, la causa real que provocó la oposición radical a Jesús, tanto por parte de los que se creían religiosos (los fariseos) como de los políticos (los partidarios de Herodes) fue que puso el bien del ser humano como expresión máxima de lo que Dios queria y esperaba de su pueblo, de modo que pasara incluso por encima de una ley tan santa como la de guardar el sábado (cfr. Mc 3,1-6; también Mc 2,23-28; Jn 9).

6. K. Lehmann, Jesucristo resucitado, nuestra esperanza, Santander: Editorial Sal Terrae, 1982 , pp. 72 y s. 
Con ello - como hizo luego aquel gran discípulo de Jesús que fue Mons. Romero - Jesús denunciaba la injusticia económica, social, religiosa y política que tantas víctimas provocaba $-\mathrm{y}$ sigue provocando- en el mundo.

Por eso lo mataron? Y Y lo hicieron para ver si así conseguían acallar su voz. Por ello, predicar que Dios le había resucitado era reconocer que Jesús, y no sus opositores y verdugos, tenía razón. Era dar mayor resonancia aún a la voz de Jesús de Nazaret, lo cual tenía que molestar obviamente a los poderes injustos de este mundo.

Pero desde la experiencia pascual, los discípulos, que en la pasión lo habían abandonado por miedo ( $c f$. Mc 14,50), fueron capaces de seguirle en el camino (eso es lo que presupone Mc 16,7) que, en un mundo injusto, conduce a la cruz, como ya Jesús les había advertido (cfr. Mc 8,34). Y atribuyeron al Resucitado algo que cambió radicalmente sus vidas, como cambió también la de Pablo (cfr. 1 Co 15,8-11). Y les puso en la picota de los poderes fácticos que habían rechazado a Jesús.

A partir de este hecho podemos entender por qué J. M. Castillo ${ }^{8}$ saca, con razón, la siguiente conclusión:

Por lo tanto, se puede decir que cuantos sufren el mismo tipo de persecución que sufrió Jesús, ésos son quienes viven la primera y fundamental forma de presencia del resucitado en sus vidas, mientras que, por el contrario, quienes jamás se han visto perseguidos o molestados, quienes siempre viven aplaudidos y estimados, ésos se tienen que preguntar si su fe en la resurrección no es, más que nada, un principio ideológico con el que a lo mejor se ilusionan engañosamente.

Por esto resulta muy iluminador lo que dice Pagola9 en este contexto: "Una vida crucificada y entregada al servicio y en defensa de los crucificados es la mejor expresión de fe viva en el Resucitado".

7. Cfr. X. Alegre, "Los responsables de la muerte de Jesús", Revista Latinoamericana de Teología 14 (1997) 139-172.

8. J. M. Castillo, “¿Cómo, dónde y en quién está presente y actúa el Señor resucitado?”, Sal Terrae 70 (1982) 211.

9. J. A. Pagola, óp. cit., p. 17. En la misma línea J. Sobrino, en "La Pascua de Jesús y la revelación de Dios desde la perspectiva de las víctimas", Sal Terrae 83 (1995) 205, saca la siguiente conclusión: "Por decirlo desde el principio, el misterio pascual revela: 1) a un Dios parcial hacia las víctimas, a las que hace justicia; 2) a un Dios en lucha con los dioses, "perdedor" y "vencedor", digamos, a lo largo de la historia; 3) a un Dios que es, a la vez, mayor y menor, dialéctico por lo tanto; y, por ello, 4) a un Dios que sólo al final será todo en todo, y de ahí su futuridad. Correlativamente, la fe - en el sentido de fides qua - en ese Dios significa: 1) esperanza en que el verdugo no triunfará sobre la víctima; 2) praxis agonista contra los ídolos; 3) dejar a Dios ser Dios, misterio absoluto; y 4) caminar humildemente en la historia hasta su consumación". 


\section{El lenguaje empleado por el Nuevo Testamento}

Por lo que indican los textos bíblicos, predicar la resurrección de Jesús implicaba también otro aspecto fundamental. Significaba que Jesús se hacía ahora realmente presente en la comunidad.

Por un lado, era el mismo Jestís que los discípulos habían conocido y acompañado en su vida pública, y que había muerto crucificado. Pero su presencia era distinta. Ya no era lo mismo. El Dios creador lo había resucitado (cfr. $\operatorname{Rm} 4,17$; 10,$9 ; 1$ Co 6,14), iniciando así el final de los tiempos ${ }^{10}$. Por ello, al querer comunicar qué es lo que ellos habían experimentado en la Pascua se encontraron con lo que se ha denominado "una barrera del lenguaje". Pues si el cambio que los discípulos experimentaron en la Pascua fue algo "histórico", lo que le había ocurrido a Jesús - y que según todos los testimonios bíblicos está en el origen de la fe pascual de los discípulos - era algo "metahistórico".

Y los autores lo denominan metahistórico "para expresar - como indica J. Lois ${ }^{11}$ - que, sin ser un hecho histórico, es, no obstante, una acción real de Dios que afectó realmente a Jesús - el cual sí fue un ser histórico, situado en el espacio y el tiempo - y [afectó] también el curso entero de la historia por irrumpir en ella la vida nueva del Resucitado, como arras de una plenitud definitiva que es activamente esperada por los creyentes".

10. Como señala J. Lois, La experiencia del Resucitado, en los primeros testigos y en nosotros hoy, Vitoria, 2002, p. 16: "esa acción de Dios (...) es un acontecimiento escatológico mediante el cual irrumpe en Jesús lo último, lo definitivo. Un acontecimiento absolutamente singular y trascendente, que no puede ser homologado con hecho histórico alguno, al estar sustraído a las coordenadas del espacio y del tiempo". Y que sólo puede ser captado por los ojos de la fe (Rousselot). Pues, como indica J. L. Segundo, El hombre de hoy ante Jesús de Nazaret, vol. II/1, Madrid: Ediciones Cristiandad, 1982, p. 265, "la presencia de lo escatológico se da sin necesidad de quebrar o sustituir ley natural alguna", por lo que no es accesible, sin más, a la visión del no creyente. Este aspecto del papel de la fe lo explica bien Lois, ibid., pp. 20-24. Según este autor (ibíd., p. 21), "la resurrección de Jesús se hace accesible al ser humano únicamente al convertirse en acontecimiento revelatorio, es decir, al ser comunicada por manifestación del mismo resucitado o por la declaración creyente de los primeros testigos a quienes se concedió tal manifestación. Y a ese acontecimiento revelatorio sólo puede responder la fe que acoge y confía. Es precisamente mediante la fe de esos primeros testigos como el resucitado ingresa en la historia".

11. J. Lois, La experiencia del Resucitado, óp. cit., p. 16. En este contexto pienso que es importante subrayar que la resurrección de Jesús no es meramente una creaciôn de la fe de los discípulos. Pues, como señala H. Kessler, óp. cit., p. 203, "no es el creyente el que produce la resurrección de Jesús (la resurrección de Jesús no es una creación de la fe); Jesús no es el Resucitado porque nosotros u otros crean en él. Fue, a la inversa, el Resucitado es el que generó con su encuentro, antes de toda fe y como Crucificado resucitado, la fe de los discípulos". 
En este contexto, los especialistas destacan, con razón, la pluralidad del vocabulario que el Nuevo Testamento emplea para hablar de la resurrección de Jesús (y de sus apariciones) y la manera muy sobria con que las confesiones de fe más antiguas dan testimonio de la resurrección y de las apariciones del Resucitado.

J. Delorme ${ }^{12}$ distingue tres tipos de lenguaje, cada uno con sus características propias, con sus ventajas e inconvenientes a la hora de expresar en palabras el fenómeno que solemos denominar la resurrección de Jesús. Son el lenguaje de resurrección (cfr. 1 Co 15,4; Hch 3,15; 2,24.32, etc.: es el más abundante), el de vida (cfr. $\mathrm{Rm} 14,9 ; \mathrm{Hb} 7,25 ; 1$ Pe 3,18; Ap 1,18...) y el de exaltación (cfr. Flp 2,9; Hch 3,$13 ; 5,31 ; 1 \mathrm{Tm} 3,16$ ). Dichos lenguajes no siempre estuvieron unidos desde el inicio. Pero todos ellos parecen implicar, aunque de modo distinto, que por una acción sorprendente creadora de Dios algo le ha ocurrido a Jesûs mismo ${ }^{13}$. El lenguaje que acabó dominando fue el de resurrección, por cuanto la palabra en griego significa "levantarse", "despertar del sueño", y resulta así una buena metáfora para aludir a una realidad que, en principio, escapa al ser humano que se encuentra siempre más acá de la muerte, pues puede ver en el dormir y en el despertar un símbolo del "resucitar de entre los muertos".

Llama la atención, por tanto, que los textos más antiguos (fundamentalmente confesiones de fe, pero también himnos litúrgicos) reflejen la conciencia de que sus autores se vieron confrontados con un fenómeno - me refiero al fenómeno pascual - que superaba, en cierto modo, su experiencia ordinaria y las posibilidades del lenguaje.

En el fondo nos encontramos, como he indicado antes y como señala A. Vögtle ${ }^{14}$, utilizando una fórmula de R. Schnackenburg, ante una "barrera de lenguaje

12. Cfr. J. Delorme, "La resurrección de Jesús en el lenguaje del Nuevo Testamento", en H. Cazelles; J. Delorme; L. Derousseaux; J. le Du; y R. Mace, El lenguaje de la fe en la Escritura y en el mundo actual, Salamanca, 1973, p. 109-140, donde, con ayuda del Antiguo Testamento, explica las ventajas y las dificultades de cada uno de los lenguajes que se emplean.

13. Por eso A. Torres Queiruga resume así lo que es el núcleo de la fe cristiana en la resurrección, al margen de las diferentes interpretaciones que puedan darse de ella: "Jesús de Nazaret no acabó en la cruz. No sabemos cómo, pero creemos que él en persona (no como un simple recuerdo o entelequia) entró en la vida eterna, y que por lo tanto no quedó reducido a la nada, sino que fue glorificado y exaltado. Esta glorificación que lo eleva sobre el mundo no significa que se 'marchó' de la historia, sino que sigue presente, con el mismo cariño y la misma preocupación, ahora potenciados e identificados con el amor infinito y universal del Padre. Este destino tiene significado para nosotros en cuanto nos revela el destino que Dios quiere para todas y todos: si Cristo resucitó, también nosotros resucitaremos; si nosotros resucitamos, señal de que Cristo resucitó" ("La resurrección: unidad de fe, pluralismo de interpretaciones", Selecciones de Teología 47 (2008) 133 y s.).

14. En A. Vogtle y R. Pesch, Wie kam es zum Osterglauben?, Düsseldorf, 1975, p. 12. Podemos preguntarnos también por qué se habla, con todo, de resurrección "corporal". Según J. Lois, óp. cit, p. 18, "Lorenzen aclara bien el alcance de tal expresión: “El Nuevo 
[religioso] de primer grado". No sorprende, por lo tanto, que para expresarlo lo más adecuadamente posible recurrieran al lenguaje religioso y simbólico que les brindaba el Antiguo Testamento, bien conocido por ellos. En este sentido, el acontecimiento que provocó la fe pascual nos viene mediado, interpretado, por unas determinadas categorías religiosas: las del Antiguo Testamento ${ }^{15}$.

Y subrayo el aspecto simbólico del lenguaje sobre la resurrección porque, como indica P. Grelot ${ }^{16}$, no se puede hablar de la muerte y del "más allá" sin recurrir al registro del lenguaje simbólico, un lenguaje que

...encierra varios "registros" diferentes: un registro "analógico" (mi relación con Dios es análoga a la relación del niño con su Padre); un registro "figurativo", que pertenece en propiedad a la Biblia para traducir la relación entre los dos Testamentos; un registro "mítico" para hablar de lo que de ningún modo puede caer bajo el dominio de los sentidos: Dios está "en el cielo", y existe, inversamente, un "lugar" simbólico de la muerte y del mal "allí abajo", en los "infiernos", en el extremo opuesto del cielo como "lugar de Dios". Por la misma razón, los orígenes y el "fin" escapan radicalmente a nuestras percepciones sensoriales o incluso intelectuales: brotan de un dominio "mítico" en el lenguaje simbólico.

Por otro lado, se ha subrayado, con razón, que la doctrina de la resurrección de los muertos no se encuentra en la mayor parte del Antiguo Testamento. Es más bien una doctrina tardía que florece en el movimiento apocalíptico, cuando la comunidad se ve confrontada masivamente con el hecho de la persecución y el martirio de sus miembros "justos" y tiene que plantearse la cuestión de cómo se puede creer que Dios es bueno y justo, si hay tanto sufrimiento de inocentes en el mundo. Es en este contexto que se puede ver que el concepto bíblico de resurrección tiene que ver más con una determinada idea de Dios que con un determinado pensamiento filosófico sobre el ser humano y su pervivencia más allá de la muerte.

Testamento habla de una resurrección 'corporal' .Corporal' no se refiere aquí al cuerpo particular que Jesús tenía en el momento de su muerte. Ni siquiera presupone necesariamente una tumba vacía. Significa que la persona entera de Jesús, con todas sus realizaciones y relaciones, es decir, la persona formada en y por sus relaciones y servicios, llegó a la presencia de Dios. No solo su 'alma', sino todo su ser, fue acogido en Dios y así recibió una existencia 'nueva'. La teología actual tiende a considerar que no hay base biblica para una concepción 'fisicista' del cuerpo resucitado vinculada a la reviviscencia de las células del cadáver. La significación profunda de la expresión 'resurrección corporal' parece ser entonces la de subrayar la continuidad personal, aspecto fundamental de nuestra afirmación de fe en la resurrección, como vamos a ver seguidamente".

15. Sobre el trasfondo veterotestamentario, cfr: P Grelot, "La resurrección de Jesús y su fondo bíblico y judío", en P. de Surgy, et ál., La resurrección de Cristo y la exégesis moderna, Madrid, 1974, pp. 15-52.

16. P. Grelot, "Résurrection et immortalité", Esprit et Vie 105 (1995) 578. 
En todo caso, autores como E. Schweizer ${ }^{17}$ han notado, con razón, que el hecho de que Israel tuviera durante tanto tiempo una fe profunda en Dios, sin esperar una vida después de la muerte, ayuda a evitar el peligro de que la fe cristiana en la resurrección pueda comprenderse de un modo alienante que llevara a desvalorizar las realidades terrenas.

Pero la presencia de Jesús ahora era, para los primeros testigos del Resucitado, tan real como nueva. Juan hablará de su presencia a través del Espíritu, del Paráclito ( $c f r$. In 14,15-17.25-26; 15,26-27; 16,7-15). Marcos nos dirá que para poderlo "ver" resucitado hay que fiarse de la palabra de Jesús (cfr. Mc 14,28; 16,7) e ir a Galilea. Es decir, hay que tomarse en serio la enseñanza de Jesús en Galilea, seguirle radicalmente, con la confianza de que Él, ahora resucitado, se hará presente de nuevo en sus vidas y les capacitará para vivir como Él les enseñó a vivir. Y Mateo señalará que ahora se hace sacramentalmente presente en el pequeño, el pobre, el marginado, del que uno se haga prójimo, solidario ( $c f r$. Mt 25,31-46).

Porque el Resucitado se hace ahora presente allí donde la vida (el Amor) lucha contra la muerte ( $c f r$. Rm 6,4.5.9; Flp 3,10-11). Por tanto, no solo se hace presente en "la otra vida", sino, ahora y aquí ( $c$ fr. Col 2,12-13: ¡en presente!), en "la vida otra", la vida alternativa, que tiene su origen y punto de referencia en la vida de Jesús de Nazaret. Es el Jesús que, como señala Lucas (cfr. Hch 1,11), nos invita a no quedarnos mirando al cielo, sino a luchar, por fidelidad a Jesús, contra todos lo que se opone al Reinado de Dios.

Se hace ahora presente donde se vive una esperanza incombustible, contra toda esperanza meramente humana, porque no hay ningún fracaso, ninguna muerte o martirio, en el trabajo por la construcción del Reino que nos pueda desalentar definitivamente (cfr. Jn 5,24; 11,25-26; Rm 8,11; Jn 8,51) ${ }^{18}$.

Desgraciadamente, muchos cristianos se imaginan la resurrección de Jesús más como un retorno a la vida de este mundo (algo que se podía ver con los ojos de la carne) que como el acontecimiento que dio pie a la fundación de su comunidad o que está en el origen de su fe en Dios. Y esta es una de las causas que dificulta su fe en el Resucitado.

17. E. Schweizer, "La resurrección de Jesús, ¿realidad o ilusión?", Selecciones de Teología 21 (1982) 3-12.

18. Pues, como señala Castillo, óp. cit, pp. 212 y s., "la resurrección se hace presente y se manifiesta allí donde se lucha y hasta se muere por evitar la muerte que está a nuestro alcance y por suprimir el sufrimiento que se puede evitar. $\mathrm{Y}$ aquí es donde, sobre todo, tiene que hacerse patente y tangible la fe en la resurrección: sufriendo por suprimir el sufrimiento y hasta muriendo por evitar la muerte. De tal manera que la fe en la resurrección es lo que tiene que ser en la medida en que se acerca a esta forma de praxis, es decir, en la medida en que se acerca a este compromiso práctico con la vida y a favor de la vida". 
Según J. Doré ${ }^{19}$, las opiniones que hoy se tienen a propósito de la resurrección de Jesús son de cuatro tipos según que predomine una actitud objetivista (hubo una constatación, en cierto modo objetiva y neutra, de la realidad de la tumba vacía y de las apariciones a los discípulos, y los testimonios que ellos nos dan son objetivos); o bien una actitud subjetivista (los testigos no dicen que constataran la resurrección ni que tuvieran "pruebas" de ella, sino que lo creyeron y que comprometieron su vida por esta fe; por tanto, no se puede excluir absolutamente una equivocación de buena fe), pues todo sucedió en el corazón de los apóstoles: en esta línea se puede comprender la resurrección de Jesús como el símbolo de una verdad general, accesible a todo el mundo, al margen de cualquier referencia cristiana. Esto supuesto, las cuatro posturas posibles serían:

1. Jesús ha vuelto a tomar posesión de su cadáver, ahora está, como cuerpo glorioso, a la derecha del Padre. La tumba vacía y las apariciones son datos históricos, pues se encuentran en el Nuevo Testamento. No verlo así significaría no tener fe. La resurrección de Jesús, por tanto, prueba, apologéticamente, que Jesús es Dios.

2. Jesús está vivo personalmente, pero no sabemos cómo es esta vida, ni lo que esta afirmación implica para nuestro modo de ver a Dios o para la identidad de Jesús. Es bueno tener una cierta docta ignorancia, pues la presentación literaria y apologética del Nuevo Testamento no permite saber más. Lo importante no es tanto el contenido de esta fe, cuanto la conversión y el compromiso que comporta el luchar contra todo lo que hay de mortiffero en nuestra vida y en el mundo. Jesús es una llamada única a una vida llena de sentido y el camino hacia una esperanza fundada.

3. No se preocupa de lo que le ocurrió a Jesús. Tan solo se puede decir que "Jesús vive" para aquellos que hoy se refieren a Él. No se trata, pues, de que Jesús sobreviva, sino de que nosotros tomemos la antorcha que Él dejó. Lo que perdura es su "causa", su "espíritu". En este supuesto, no es necesario aceptar toda la dogmática cristiana para entender que ciertos valores e ideales tienen su origen en Jesús: es revivir entre los hombres aquello que tomó cuerpo en Jesús de Nazaret y que, de hecho, no murió con Él.

4. La resurrección de Jesús es tan solo como una "clave", tan solo como un símbolo de una verdad que es humana y universal (al margen de Jesús): que en ciertas condiciones el bien puede brotar siempre del mal; que se puede tener esperanza contra toda esperanza; que hasta la muerte tiene sentido si permite llegar a la auténtica sabiduría o a la entrega a los demás como un servicio. En Occidente, esto se ha unido a Jesús. Pero no ha de ser siempre así. Jesús está muerto. Paradójicamente, Él enseñó a los seres humanos a

19. J. Doré, “Creo en la resurrección de Jesucristo", Selecciones de Teología 22 (1983) 84-87. 
vivir sin Dios y sin dioses, incluso sin Jesucristo. En contra de sus adversarios, Jesús tenía razón al vivir y morir como lo hizo: el amor y el servicio desinteresado pueden dar sentido pleno a una vida.

5. Podríamos añadir también una quinta postura, propia de los que toman una postura negativa beligerante frente a la fe cristiana. Según ellos, la resurrección de Jesús fue un engaño de los discípulos que inventaron los relatos de la tumba vacía y de las apariciones a los discípulos para poder dar sentido a lo que habían estado haciendo hasta entonces y superar así el trauma de la cruz. Algunos de ellos sostienen que lo habrían hecho de mala fe; según otros, fue la consecuencia de un mecanismo psicológico inconsciente. Más tarde otros discípulos, ilusionados y engañados, se lo creyeron y así fue tomando cuerpo la leyenda de la resurrección de Jesús ${ }^{20}$.

En todo caso, se entienda como se entienda la resurrección, para la mayoría de autores parece que es un hecho histórico que la muerte de Jesús provocó una crisis de fe en sus discípulos ${ }^{21}$. Por ello resultaría sorprendente que tan pronto hubieran recuperado la fe, si no ocurrió algo especial que provocó en ellos un cambio tan radical, que no solo les llevó a recuperar la fe en Jesús, a un nivel superior al que habían tenido en vida de Jesús, sino que fueron incluso capaces de dar su vida por Él. Sobre todo llama la atención que fueran capaces de "inventar" una doctrina en principio tan nueva, pues la resurrección de los muertos se esperaba, si acaso, para el fin de los tiempos. Y se esperaba una resurrección universal, no solo de una persona individual ${ }^{22}$.

20. Cfr. ibíd., p. 88 .

21. Cfr. Lorenzen (óp. cit., pp. 163-167). Y que la recuperación de la fe no se debió tan solo a una predisposición psicológica de los discípulos. "Existe un consenso generalizado en que las fuentes neotestamentarias hablan de un encuentro real de Cristo resucitado con los discípulos; en que dicho encuentro tuvo lugar por iniciativa de Dios mismo; en que no fue generado por la configuración psicológica de los discípulos, sino que se produjo desde el exterior de los discípulos; y en que no solo les sucedió algo a los discípulos, sino también a Jesús mismo. (...) El argumento exegético está apoyado por el argumento histórico de que en las vidas de los discípulos tuvo lugar un cambio espectacular" (ibíd., pp. 168 y s.). Pero hay autores, como R. Pesch y A. Torres Queiruga, que piensan que no hubo tal crisis radical en los discípulos, y proponen, a modo de "hipótesis" interpretativa alternativa, otras conjeturas y motivos accidentales para explicar cómo los discípulos de Jesús llegaron a creer que Jesús había resucitado ( $c f r$ A. Torres Queiruga, óp. cit., pp. 136 y s.).

22. Así opina Lorenzen, op. cit., p. 163. Por eso Fraijó, óp. cit., p. 210, comenta: “El judaísmo no desconocía (...) el tema de la resurrección; pero sólo la concebía en dimensiones cósmicas y al final de los tiempos. El hecho de que un ser humano la anticipase en el fluir de nuestra historia, rompía todo esquema. Y, sin esquemas, sin modelos de referencia, casi es imposible inventar. Hay que afirmar que, con toda probabilidad, después de la muerte de Jesús, a los discípulos les ocurrió 'algo', tuvieron alguna ex- 
De hecho, cuando ellos cuentan su experiencia (al menos según los testimonios bíblicos), afirman, como veremos, que fueron experiencias inesperadas que les vinieron "de fuera", aunque fueran interiores y no excluyeran la fe.

Pero estas experiencias pascuales son tan novedosas que, cuando quieren contarlas catequéticamente, han de hablar, a la vez, de ver y no ver, de tocar y no tocar, de reconocer y no reconocer, de aparecer y desaparecer. Pues, como hemos visto, son bien conscientes de que se enfrentan a una auténtica "barrera del lenguaje", ya que han de expresar en qué medida la realidad divina está ahora afectando a Jesús. Pues no se trata de narrar simplemente el retorno de Jesús a esta vida (como supuestamente ocurrió en la resurrección de Lázaro o del hijo de la viuda de Naím). Por ello, como señala P. Perkins ${ }^{23}$.

La resurrección no puede ser descrita, por tanto, como un acontecimiento histórico, en el sentido ordinario de la palabra. No hay ningún testimonio humano del acontecimiento mismo de la resurrección de Jesús. El Nuevo Testamento lo presenta como un acto escatológico de Dios, como parte de la transformación final del mundo. Esto implica que es algo más que la vindicación de una persona particular. La salvación de Dios está de tal modo implicada con Jesús que, después de Pascua, Jesús se convierte en la norma de la relación de la humanidad con Dios.

Si se trata de un "acontecimiento escatológico", esto significa que es distinto de una intervención milagrosa en el orden natural (por ejemplo devolver la vida a un cadáver). Por ello, esto implica también que se trata de un acontecimiento para Jesús y no solo de un cambio de conciencia de los discípulos.

La variedad de tradiciones y de tipo de testimonio hace que no sea posible reducir la resurrección a la proyección de la necesidad de los discípulos de recuperar la "intimidad embriagadora" de su compañerismo con Jesús.

$\mathrm{Al}$ ser un "acontecimiento escatológico", ello implica que la realidad "corporal" que comporta la resurrección está en discontinuidad con la realidad corporal que experimentamos. Como un "acto nuevo de Dios", la resurrección

periencia determinante. Probablemente vivieron un 'proceso de conversión' (Schillebeeckx) activado por varios factores: el recuerdo de la actuación y mensaje de Jesús, la reflexión sobre su anuncio de un Dios misericordioso que perdona sin condiciones, la meditación serena sobre el destino del profeta sufriente, la evocación de las comidas celebradas con él. Tampoco se puede excluir que, a todo lo anterior, se añadieran nuevas experiencias, acontecidas después de la muerte de Jesús. Experiencias tal vez de tipo espiritual que los discípulos expresaron por medio de las narraciones sobre las apariciones y sobre la tumba vacía”. En cambio, A. Torres Queiruga ( $c f r$ Repensar la resurrección, Madrid: Trotta Editorial, 2003, pp. 69-72), no lo interpreta así.

23. P Perkins, Resurrection. New Testament Witness and Contemporary Reflection, London, 1984 , pp. 19 y s. 
no puede ser considerada como una variante de una especulación filosófica, universal, sobre la supervivencia humana. Pero tampoco liga a los cristianos a las antropologías o cosmologías del código apocalíptico en las cuales se originó la fe en la resurrección.

¿Qué pasó, entonces? Pagola ${ }^{24}$ lo explica así: "Se trata de una experiencia compartida probablemente por bastantes, repetida en diversas circunstancias, y que ellos tratan de describir, de alguna manera, acudiendo a diversos lenguajes y procedimientos narrativos (Jesús es el de antes, pero no es el mismo; está en medio de los suyos, pero no le pueden retener; es alguien real y concreto, pero no pueden convivir con él como antes). Los relatos nunca nos describen el acontecimiento mismo de la resurrección. Los discípulos hablan de su encuentro con el ya resucitado, que se les impone lleno de vida y transforma radicalmente sus personas".

Es obvio, pues, que los relatos pascuales no pretendan ser videos de lo que pasó, sino relatos simbólico-teológicos, empleados en la liturgia y en la catequesis, para provocar en los oyentes la conciencia de que también ellos, ahora, podían hacer experiencias del Resucitado. Los encuentros con el Resucitado carecieron de la masividad y evidencia que parecen presuponer los textos. Por otro lado, sería, en principio, una inconsecuencia que los que fueron los iniciadores de la fe cristiana no hubieran necesitado de la fe para poder hacer sus experiencias. Lo que denominamos la Resurrección de Jesús no puede ser demostrado "empíricamente". Pero sí tiene unas garantías serias que apoyan su credibilidad.

\section{Los textos más antiguos de confesiones de fe}

Hoy se está de acuerdo en que los textos más antiguos que hablan de la resurrección de Jesús se encuentran en fórmulas breves y muy sobrias. De hecho, en las cartas paulinas (y de la tradición paulina) encontramos una serie de fórmulas fijas que por sus características (tanto en su terminología como en su forma) puede verse que son anteriores a Pablo, el autor más antiguo del Nuevo Testamento. La fórmula, con pequeñas variantes, "Dios ha resucitado a Jesús de entre los muertos" se ve cada vez más como el núcleo más antiguo de la Tradición de la resurrección ( $c f r$. $\operatorname{Rm} 4,24 ; 8,11 \mathrm{ab} ; 2$ Co 4,14). En todas ellas se presupone que Dios es el sujeto de las afirmaciones.

Pero por sí solas, dichas fórmulas no nos clarifican adecuadamente qué entendían los que las formularon cuando confesaban que Dios había resucitado a Jesús. Por eso pronto se fueron ampliando.

24. J. A. Pagola, “El Seňor ha resucitado'. Relato de una experiencia; consecuencias de un encuentro", Sal Terrae 70 (1982) 168. 


\section{Significado de $1^{\text {a }}$ Corintios 15,3-5}

Todos los autores subrayan la antigüedad y el interés de una fórmula bimembre, acuñada probablemente en Antioquía pocos años después de la muerte de Jesús, que encontramos en 1 Co 15,3-5, pues no se limita a proclamar el hecho de la "resurrección" de Jesús. Es muy sencilla y está construida de modo que sus dos miembros sean paralelos, de acuerdo con un rasgo típico de la poesía hebrea (aquí se trata de una confesión de fe y el paralelismo facilita el mantenimiento y asimilación del texto). Pablo recuerda en ella a los cristianos de Corinto unos elementos fundamentales de la tradición cristiana más antigua, que él recibió por tradición: "Porque yo os transmití, en primer lugar, lo que yo a mi vez recibi":

Que Cristo murió por nuestros pecados según las Escrituras

y que fue sepultado;

y resucitó al tercer día según las Escrituras,

y se apareció a Pedro, y luego a los Doce.

Varias son las cosas que vale la pena destacar en el texto. Las afirmaciones fundamentales son dos: "que Cristo murió" y que "resucitó" (la voz pasiva de la fórmula griega empleada implica que "Dios le resucitó").

La muerte de Jesús viene reinterpretada, en primer lugar, por dos fórmulas teológicas: "murió por nuestros pecados" (y no porque fuera un blasfemo o un terrorista) y con ello "se cumplió lo anunciado por las Escrituras", es decir, por el Antiguo Testamento. Y viene confirmada por el hecho de que fue sepultado, lo cual era condición, en la antropología judía, para poder afirmar que un personaje habia muerto realmente (la mayoría de autores piensa, a mi juicio con razón, que aquí Pablo - al igual de lo que ocurre en el resto de sus cartas, en las que nunca habla de la tumba vacía - no alude al descubrimiento de la tumba vacía).

Lo que acabamos de ver nos permite sospechar, dado el paralelismo con que están construidos los dos miembros de la confesión de fe que las fórmulas "al tercer dia" y "segûn las Escrituras" son también calificaciones teológicas del hecho de que Dios resucitó a Jesús. Y esto vale —en contra de lo que espontáneamente hacemos nosotros, que leemos la fórmula a la luz de los relatos evangélicos del hallazgo de la tumba abierta y vacía en la mañana del domingo de Pascua - para la afirmación de que resucitó "al tercer día". La indicación "al tercer día" sería, como el "según las Escrituras", un dato teológico y no se refiere, por tanto, al día histórico en que Jesús resucitó o se apareció por primera vez o en el cual fue encontrada la tumba abierta y vacía (los relatos que contienen esta interpretación son posteriores). Según K. Lehmann ${ }^{25}$, hay que interpretar la fórmula como calificación de un momento salvífico fundamental: aquél en el cual Dios interviene para salvar al pueblo (aquí, a Jesús).

25. K. Lehmann, Auferweckt am dritten Tage nach der Schrift, Freiburg, 1968, pp. 262-290. 
La fórmula "se apareció a Pedro y luego a los Doce" sería, como el "fue sepultado" en el texto paralelo que habla de la muerte, la confirmación de que Dios habría resucitado realmente a Jesús. Sobre el significado del "se apareció a" volveré más adelante a propósito del testimonio de Pablo sobre su experiencia pascual. Aquí sólo quisiera señalar dos cosas.

Por un lado, que la fórmula diga que "se apareció a Pedro y luego a los Doce" parece implicar que el primer testigo de una aparición de Jesús fue Pedro, tal como parece presuponer también el final del relato de la aparición de Jesús a los discípulos de Emaús (éstos, al regresar a Jerusalén, encuentran reunidos a los Once y a todos los demás que les dicen según Lc 24,34: "Es verdad, el Señor ha resucitado y se ha aparecido a Simón") ${ }^{26}$.

$\mathrm{Y}$, por otro, que el contexto de la confesión de fe (cfr. 1 Co 15,7.8-11) mues tra que cada vez fue más necesario asegurar, con ayuda de los testigos "oficia les" de las apariciones del Resucitado, el mensaje de la resurrección frente al entorno helenista.

De todos modos dicha fórmula, aparte de emplear la categoría de "resurrección" (señalando con el tiempo griego, el perfecto, que los efectos de dicha resurrección perduran hasta ahora), no nos indica, concretamente, en qué consistió dicha resurrección, pues las calificaciones que la acompañan son teológicas: indican, ante todo, el significado del acontecimiento.

\section{El testimonio de un testigo personal, Pablo}

El único testigo del cual tenemos un testimonio personal de una aparición del Resucitado es Pablo. Por eso su testimonio resulta especialmente interesante para

26. Esto es lo que parecen presuponer los textos evangélicos canónicos actuales. Desde una lectura feminista - y apoyándose sobre todo en Jn 20,10-18 - se ha cuestionado este dato y se lo ha reinterpretado como una relectura posterior, de cuño más bien machista, que ha intentado ocultar, por intereses de poder eclesiástico y por prejuicios antropológicos propios - aunque no exclusivos - del mundo judío, el papel fundamental que desempeñó una mujer como María Magdalena en los inicios de la fe cristiana. De hecho, en otro contexto cultural, concretamente en Roma, encontramos, según Rm 16,7, a una mujer, Junia, que es alabada por Pablo como “insigne entre los apóstoles" (sobre el significado del texto, cfr. X. Alegre, "Junia, ¿una mujer apóstol (Rm 16,7)?", en X. Alegre, Memoria subversiva y esperanza para los pueblos crucificados, Madrid: Trotta Editorial, 2003, pp. 335-351). Pero desde el punto de vista histórico es difícil saber, con las fuentes con las cuales contamos ahora y dado el interés primariamente teológico y catequético de los relatos de aparición pascual (también vale esto para In 20,10-18), qué ocurrió realmente: Si fue Pedro o más bien María Magdalena la primera que tuvo una aparición de Jesús resucitado. En todo caso, en el mundo judío de la primera comunidad cristiana, en el cual las mujeres estaban religiosamente marginadas, una aparición a María Magdalena no pudo tener el significado y el influjo que debió tener la aparición a Pedro. 
procurar descubrir qué es lo que debió ocurrir históricamente en los testigos de una aparición pascual.

\subsection{El testimonio de $1^{\text {a }}$ Corintios}

Llama la atención, en primer lugar, que sin haber conocido personalmente a Jesús ni haber creído en él anteriormente (él mismo subraya que perseguía a la comunidad cristiana), sin embargo coloque su aparición pascual (que es posterior a las de los otros testigos) - por lo menos de acuerdo con la terminología que utiliza en 1 Co 15,8- al mismo nivel que las apariciones a Pedro, a los Doce, a Santiago, el hermano de Jesús, y al resto de los Apóstoles (cfr. 1 Co 15,5.7). Pues en 1 Co 15,8 designa su aparición pascual también con la fórmula "técnica" ôphthê + dativo de persona. ¿Qué implica dicha fórmula en orden a descubrir qué es lo que Pablo (y los otros testigos) experimentó? Veámosla primero en su contexto:

Y después de todos se me apareció a mí, como si de un hijo nacido a destiempo se tratara. Yo, que soy el menor de los apóstoles, indigno de llamarme apóstol por haber perseguido a la Iglesia de Dios. Pero por la gracia de Dios soy lo que soy, y la gracia de Dios no ha sido estéril en mí. Al contrario, he trabajado más que todos los demás; bueno, no yo, sino la gracia de Dios conmigo. En cualquier caso, tanto ellos, como yo, esto es lo que anunciamos y esto es lo que habéis creído. (1 Co 15,8-11.)

La fórmula puede ser interpretada de tres maneras: a) como pasiva: "él fue visto por..."; b) como pasivo divino con el sentido de "él fue hecho visible por Dios"; c) como deponente: "él se dejó (mejor: se hizo) ver por". Este último sentido se encuentra en el griego profano, en los papiros mágicos (como fórmula de conjuro) y, sobre todo, en la traducción de la Biblia hebrea al griego, denominada de los LXX, que es la que probablemente influiría en el uso que el Nuevo Testamento hace de la fórmula. El Antiguo Testamento la utiliza unas 45 veces y la emplea para la aparición de Yahvé o de su ángel a Abraham, Isaac, Jacob, Moisés y a otras figuras de la historia de Israel (David y Salomón). El códice sacerdotal (P) habla, además, de la aparición de la gloria de Dios en la tienda del encuentro: es expresión de la iniciativa gratuita de Yahvé en la historia de $\operatorname{Israel}^{27}$. Se ha hecho notar también que, tal como indica 2 Macabeos 2,8, lo específico de esta fórmula es que significa el retorno del tiempo salvifico que fue realidad, en cierto modo, en el tiempo de los

27. Filón en De Abrahamo 8 señala que Génesis utiliza esta fórmula en el cap. 12 para indicar que "Dios fue a su encuentro (de Abraham) y de su naturaleza le mostró lo que era capaz de ver el que miraba. Por eso dice no que el sabio vio a Dios, sino que Dios se hizo ver del sabio". La fórmula, pues, responde al "niphal" en hebreo de ver y cuando el sujeto es una persona, el contexto indica que se trata del acto de mostrarse o presentarse de alguien y corresponde, más bien, a la forma hebrea causativa "Hiphil" y habría que traducirlo: "se hizo ver de". 
Patriarcas, del Éxodo, de David y de Salomón (implica que ahora empieza el tiempo definitivo que Ap 21,3 expresa como esperanza apocalíptica).

La fórmula se emplea en el Nuevo Testamento también para la aparición de Cristo a Pablo (Hch 9,17; 26,16); para la aparición de un ángel (Lc 1,11; 22,43; Hch 7,30 [= Ex 3,2].35); para una aparición en sueños (Hch 16,9); para la aparición de las lenguas de fuego el día de Pentecostés (Hch 2,3); para la de Elías y Moisés en la Transfiguración de Jesús (Mc 9,4par); para la de Dios a Abraham (Hch 17,2; para la de Cristo a los ángeles $(1 \mathrm{Tm} 3,16)$ y para las visiones del Apocalipsis $(11,19 ; 12,3)^{28}$.

Kessler comenta así el significado de la fórmula:

El sujeto iniciador y activo de todo el acontecer es, pues, Dios o Jesucristo (no la subjetividad interpretadora de los discípulos). Estos son receptores de las apariciones, lo que no excluye su participación activa con las facultades perceptivas, sino que la incluye (ellos ven al que se deja ver). El momento del ver está contenido claramente en el término ophthe del lenguaje de los LXX y no debe atenuarse en favor de una mera recepción de la palabra. Se trata, pues, de un "nuevo encuentro con el Resucitado en y desde la autoridad de Dios", de "una visión de Jesús crucificado y llamado por Dios a la vida definitiva". El modo concreto de esta visión queda en la penumbra. ${ }^{29}$

28. P. Hoffmann saca esas conclusiones del análisis linguístico: "El momento visual se ha mantenido tanto en la LXX como también en el Nuevo Testamento. El significado de la expresión no se puede fijar unilateralmente; viene determinado por el contexto respectivo. Si la fórmula neotestamentaria asume la fórmula veterotestamentaria de la aparición de Yahvé para describir la aparición de Cristo, coloca, sin duda, esta experiencia en un contexto interpretativo teológicamente significativo; sin embargo, con ello toma también un término corriente en las epifanías, con el cual se puede designar apariciones de diverso tipo y origen" (TRE IV 493).

29. H. Kessler, La resurrección de Jesús, óp. cit., pp. 120 y s. Pero para comprender mejor el tipo de visión que el texto implica, conviene tener presente lo que Delorme dice a propósito de la aparición de Yahvé a los padres de Sansón ( $c f r$. Jue 13) en "La resurrección de Jesús en el lenguaje del Nuevo Testamento", óp. cit., pp. 143 y s. (pueden verse allí las citas bíblicas con las cuales corrobora su interpretación): "se ofrece el sello de la aparición precisamente al cesar ésta. Es la prueba de que la iniciativa le corresponde al ser que se muestra; normalmente se le reconoce como invisible. Este lenguaje se caracteriza por un juego muy especial del eje semántico visible-invisible. Para decir que lo invisible se hace ver, hay que recurrir a los esquemas de visión, pero al mismo tiempo hay que negarlos en parte o corregirlos. "No puede verme el hombre y seguir viviendo - le dice Yahvé a Moisés- (...) apartaré mi mano para que veas mis espaldas, pero mi rostro no se puede ver' (Ex 33,20-23). [...] Otras veces los esquemas visuales tienden a eclipsarse en beneficio de los auditivos: se contenta el autor con la mención del sueño, del fuego, de la nube o de la gloria, que tienen valor de teologúmenos e incluso a veces prescinde totalmente de estas cosas, para introducir 
Según esto, la tesis sostenida por U. Wilckens ${ }^{30}$ de que la fórmula no indicaría, en principio, nada sobre el contenido de la experiencia, sino que sería simplemente una "fórmula de legitimación" que indicaría la autoridad apostólica de los personajes a los que Cristo se ha aparecido (aquí Pedro, los Doce, Santiago, los Apóstoles y Pablo), no parece que interprete de modo suficiente los textos, aunque no se cuestiona que la fórmula tenga también esta función en el contexto de $1^{\text {a }}$ Corintios.

En todo caso, si miramos la fórmula en el contexto en que la sitúa Pablo (cfr. 1 Co 15,8-11), llama la atención que Pablo no describa o explique algo de lo que "vio" o de lo que Dios "le mostró" (como tampoco en 1 Co 15,35-57 es capaz de describir cómo es el cuerpo de los resucitados).

Se limita, por un lado, y desde una perspectiva teológica, a afirmar el hecho con una fórmula ("se me apareció a mî") que, desde su trasfondo veterotestamentario, subraya la iniciativa totalmente gratuita de Dios al comunicarse con Pablo. Y, por otro, cuenta sólo dónde se encontraba él religiosamente y lo que esta "experiencia pascual" (para él única, pues la distingue de sus visiones ulteriores que él califica con otra palabra, optasiai, "visiones", y que no le confieren autoridad apostólica alguna: cfr. 2 Co 12,1) significó para él: era un perseguidor de la Iglesia y se convirtió en misionero del Crucificado/Resucitado. Sobre si vio algo o qué es lo que vio en concreto, no nos dice ni una sola palabra.

Por otro lado, llama también la atención la diversidad de terminología que utiliza Pablo para referirse a su aparición pascual. Pues en otros textos, como Ga 1,11-23 ó 1 Co 1,9 o Flp 3,7-14, Pablo utiliza un vocabulario distinto.

\subsection{El testimonio de Gálatas}

En Ga 1,11-23, por ejemplo, Pablo emplea un vocabulario de "revelación" en un texto que se refiere claramente al episodio que $\operatorname{Hechos}^{31}$ sitúa en el camino

una palabra divina. En fin, también con frecuencia el eje visible-invisible va acompañado de la oposición arriba-abajo: lo invisible que se manifiesta es de arriba (Gén 28,12); hay que subir allá cuando se entra en lo invisible (Jue 13,20) y la aparición exige la prosternación de los videntes (Ex 34,8; Jue 13,20). (...) Por sí misma, la fórmula no dice nada del género de narración que puede resumir o provocar, ni del lugar que en ella ocupan las connotaciones visuales".

30. Cfr U. Wilckens, La resurrección de Jesús. Estudio histórico-crítico del testimonio bíblico, Salamanca, 1981, pp. 26 y s. También R. Pesch, como veremos luego, interpretó inicialmente así esta fórmula.

31. Cfr. Hch 9,3-19;22,6-29;26,12-23. Ayuda a comprender mejor la forma o género literario de los relatos de aparición y a fijarse en el hecho de que el mismo Lucas, cuando narra la aparición a Pablo, emplea con libertad los detalles del relato. Pues mientras en 9,7 dice que "los hombres que lo acompañaban (...) oían la voz [que hablaba a Pablo], pero no veían a nadie", en 22,9 dice, en cambio, poniendo el texto en boca de Pablo, 
de Damasco. Y lo hace, como en $1^{\text {a }}$ Corintios, para justificar su autoridad apostólica independiente de la de Pedro. Veamos el texto concreto:

Quiero que sepáis, hermanos, que el evangelio anunciado por mí no es una invención de hombres, pues no lo recibí ni lo aprendí de hombre alguno; Jesucris to es quien me lo ha revelado. Habéis oído, sin duda, hablar de mi antigua conducta en el judaísmo: con qué furia perseguía yo a la Iglesia de Dios intentando destrozarla. Incluso aventajaba dentro del judaísmo a muchos compatriotas de mi edad como fanático partidario de las tradiciones de mis antepasados. Pero cuando Dios, que me eligió desde el seno de mi madre y me llamó por pura benevolencia, tuvo a bien revelarme a su Hijo y hacerme su mensajero entre los paganos, inmediatamente, sin consultar a hombre alguno y sin subir a Jerusalén para ver a quienes eran apóstoles antes que yo, me dirigí a Arabia y después otra vez a Damasco. Luego, al cabo de tres años, subí a Jerusalén para conocer a Pedro y permanecí junto a él quince días. No vi a ningún otro apóstol, fuera de Santiago, el hermano del Señor. En esto que os escribo, Dios es testigo de que no miento. Fui después a las regiones de Siria y Cilicia. Por entonces las iglesias cristianas de Judea no me conocían aún personalmente. Únicamente oían decir que el perseguidor de otro tiempo anunciaba ahora la fe que antes combatía.

Como vemos, en este texto Pablo fundamenta el valor de su predicación ("evangelio") en el hecho de que lo ha recibido por "revelación de Jesucristo" (cfr. Ga 1,12 y 16). Y ello ha sucedido por una iniciativa de Dios puramente gratuita, inmerecida por su parte (estaba persiguiendo a la Iglesia de Dios: cfr. Ga 1,13s). Pablo describe aquí su "experiencia" pascual en términos de revelación y con un vocabulario que recuerda las vocaciones proféticas ( $c f r$. Is 49,1-6 y Jr 1,5). Como en 1 Co 15,8-11, dicha experiencia implica, por un lado, un cambio (conversión) de vida y, por otro, una misión concreta: anunciar el evangelio a los paganos.

Es bueno caer en la cuenta de que, tal como vimos en 1 Corintios 15, tampoco aquí da Pablo ningún detalle de lo que vio u oyó (lo cual puede ser debido, naturalmente, al contexto - la apología de su dignidad apostólica- en el cual él alude a su experiencia pascual: pero nosotros no tenemos otro acceso a lo que debió ser su experiencia al margen de estos textos).

\subsection{El testimonio de Filipenses}

Muchos autores coinciden en afirmar que también en Flp 3,7-14 Pablo alude a su experiencia pascual. Tampoco aquí relata si vio u oyó algo. Se limita a indicar, como en los textos que acabamos de ver, y con un vocabulario distinto del que

que "los que venían conmigo vieron la luz, pero no oyeron la voz del que me hablaba". Lo que en todo caso quiere poner de relieve el relato es que una aparición pascual solo es accesible a aquél a quien Dios/Jesús se lo haga accesible y no es controlable, sin más, desde fuera. 
hemos encontrado en los dos textos anteriores, que dicha experiencia comportó para él un cambio radical de valores. Llama la atención que Pablo nos ofrece el mismo esquema explicativo de su experiencia pascual que hemos encontrado en 1 Corintios 15 y en Gálatas 1: a) era un perseguidor; b) hay una conversión por la iniciativa (gratuita) de Dios; y c) se le da (jestá implícito en el contexto de Flp 3!) una misión para convertir a los paganos. En ningún caso hace Pablo el más mínimo esfuerzo por "explicar" en qué consistió exactamente su experiencia pascual.

Veamos, ahora, el texto en concreto, donde Pablo, después de subrayar en los vv. 5-6 que él era un judío observante y perseguidor de la Iglesia, añade:

Pero lo que entonces consideraba una ganancia, ahora lo considero pérdida por amor a Cristo. Es más, pienso incluso que nada vale la pena si se compara con el conocimiento de Cristo Jesús, mi Señor. Por él he sacrificado todas las cosas, $\mathrm{y}$ todo lo tengo por estiércol con tal de ganar a Cristo y vivir unido a él con una salvación que no procede de la ley, sino de la fe en Cristo, una salvación que viene de Dios a través de la fe. De esta manera conoceré a Cristo y experimentaré el poder de su resurrección y compartiré sus padecimientos y moriré su muerte, a ver si alcanzo así la resurrección de entre los muertos. No pretendo decir que haya alcanzado la meta o conseguido la perfección, pero me esfuerzo a ver si la conquisto, por cuanto yo mismo he sido conquistado por Cristo Jesús. Yo, hermanos, no me hago ilusiones de haber alcanzado la meta, pero eso sí, olvidando lo que he dejado atrás, me lanzo de lleno a la consecución de lo que está delante y corro hacia la meta, hacia el premio al que Dios me llama desde lo alto por medio de Cristo Jesús.

De todos modos, hay un texto - y sería el único - en el cual Pablo parece utilizar una terminología en la cual subraya que él vio al Resucitado. Me refiero a 1 Co 9,1, donde leemos: ¿No soy libre? ¿No soy apóstol? ¿Es que no he visto yo a Jesús, nuestro Señor? ¿No sois vosotros hechura mía en el Señor?

Pero tampoco aquí nos indica Pablo concretamente qué es lo que vio realmente. Y, por el contexto (se cuestiona que él sea realmente "apóstol", con lo cual le obligan a remitir a los hechos que fundamentan su legitimidad apostólica), podría Pablo subrayar, afirmando que él recibió una aparición del Resucitado y que Corinto existe como Iglesia gracias a su predicación, que él está subjetivamente cualificado como testigo "apostólico" de la resurrección de Jesús. Pero no nos explica en qué consistió "lo que vio". De ahí que muchos especialistas prefieran hablar de "apariciones" pascuales, más que de "visiones" (aunque en el contexto actual, tanto el vocablo "aparición" como el de "visión" se prestan a malentendidos). 
De todos modos, según A. Myre ${ }^{32}$, hay consenso entre los especialistas sobre el hecho de que una aparición fue un fenómeno interior que movilizó los sentidos internos. Pero ¿en qué consistió esta "aparición/visión"?

P. Grelot ${ }^{33}$, que interpreta un texto de santo Tomás (Summa Theologica, III q. 55, art. 2 ad 1), según el cual los Apóstoles vieron al Resucitado occulata fide, dice lo siguiente: "la resurrección como tal trascendía el conocimiento común, tanto en cuanto a su terminus a quo [= la "subida de los Infiernos", que representa simbólicamente el estado de la muerte], como en cuanto a su terminus ad quem [= la vida gloriosa]" (ibíd., ad 2). No se puede, por tanto, hacer entrar en absoluto la 'visión' de Cristo resucitado en el orden de los conocimientos empíricos, si no se quiere correr el riesgo de negar la disposición subjetiva que le servía de soporte: no es la percepción sensorial la que provocaba la fe, sino que es la fe misma la que 'tenía unos ojos' (occulata fide)".

\section{Los relatos de la tumba vacía y de las apariciones del Resucitado}

\subsection{Los relatos de la tumba vacía}

La mayoría de especialistas bíblicos coincide en afirmar que el relato más antiguo de la tumba vacía es el que encontramos en Marcos 16,1-8. Por otro lado, una lectura sinóptica de los textos paralelos de Mateo 28,1-8 y Lucas 24,111 (que son posteriores y parecen depender de él; cfr. también el relato de Juan 20,1-13) ayuda a comprender el sentido de este tipo de relato y las evoluciones que experimentó en la tradición neotestamentaria.

Varias cosas llaman la atención, de entrada, en el relato de Marcos.

a) En primer lugar, no parece que quiera demostrar, al margen de la fe, que las mujeres encontraron realmente la tumba de Jesús vacía, de modo que no quepa, históricamente, otra interpretación. Pues cuando ellas llegan, la tumba ya está abierta y vacía.

b) Por otro lado, el relato no parece tan interesado en el hecho de que la tumba estuviera vacía (solo se dice de paso, al final del mensaje del joven), cuanto en la confesión de fe pascual ("Jesús de Nazaret, el Crucificado: ha resucitado"). Se trata de una revelación divina - del ángel: cfr. Mt 28,5- que interpreta lo que las mujeres ven en la tumba.

c) Tampoco se indica que el descubrimiento de la tumba vacía llevara a la fe pascual (incluso el relato de Emaús, según Lc 24,22-24, parece presuponer más bien lo contrario). Pues, según Mc 16,8, las mujeres huyeron y no dijeron nada a

32. A. Myre, "La résurrection selon le 'Catéchisme de l'Église Catholique'. Perspectives exégétiques", Science et Esprit (1996) 328.

33. P. Grelot, "La Résurrection du Christ, centre du message évangélique", Esprit et Vie 105 (1995) 133. 
nadie. En cambio, Mt 28,8 y Lc 24,8-11.22-24 dicen que sí lo contaron a los discípulos, sin que, por lo visto, a nadie le estorbara, cuando se reunieron los cuatro evangelios, esta aparente contradicción - al margen de Taciano, cuya propuesta de convertir los cuatro evangelios en uno y unificar los datos, fue rechazada por las Iglesias cristianas.

Más aún, R. Pesch, en un artículo sobre la tumba vacía ${ }^{34}$, muestra bien que si se comparan los relatos posteriores de Mateo y Lucas (también el de Juan), en los cuales el hecho de que la tumba estuviera vacía va adquiriendo cada vez más interés, con el relato más antiguo de Marcos, se constatan unas determinadas tendencias teológicas y apologéticas.

Por un lado, se ve la libertad con la cual se atreven a retocar Mateo, Lucas (y Juan) el relato de Marcos. Y, por otro, se ve también en qué sentido van cambiando los detalles del relato: tanto para profundizar su significado teológico en el marco del propio evangelio, como para evitar los malentendidos (por ejemplo, que alguien hubiera cambiado de sitio el cadáver y esto hubiera sido lo que originó la fe pascual: cfr. Jn 20,13-15) o interpretaciones de mala fe a que dicho relato pudo dar lugar (por el hecho de que la tumba estuviera ya abierta cuando 1legaron las mujeres: cfr. Mt 28,1-2 a la 1uz de Mt 27,62-66 y 28,11-15). Este modo de proceder no debería sorprendernos. Pues tanto los adversarios judíos como los creyentes cristianos desarrollaban su teología con relatos y no, simplemente, con fórmulas teológicas abstractas.

Por otro lado, conviene tener presente que si la resurrección definitiva de Jesús no es un mero volver a esta vida espaciotemporal, sino que exige una recreación por parte de Dios, un creyente bíblico estaba suficientemente familiarizado con los textos que hablan de la primera creación en forma de relatos (también plurales: compárese Gn 1,1-2,4a con Gn 2,4b-25) como para explicar la nueva creación también en forma de relato. Pues todos estos autores (a diferencia de los fundamentalistas de todos los tiempos que confunden los relatos con videos) eran muy conscientes de que si querían hablar de una acción "creadora" de Dios, la mejor forma de hacerlo era recurriendo al relato y al lenguaje simbólico.

Es por todas estas razones que para muchos intérpretes del Nuevo Testamento no queda del todo claro hoy, si las mujeres encontraron realmente vacía la tumba en la cual había sido colocado el cadáver de Jesús (no hay garantía propiamente histórica de que efectivamente fuera así, pues no podemos excluir de modo absoluto el que fuera un relato creado para explicar ulteriormente el encuentro de una tumba vacía que se atribuía - quizás sin suficientes garantías históricas - a Jesús o para contrarrestar las difamaciones de los adversarios judíos que no creían en Jesús). Desde un

34. R. Pesch, "El sepulcro vacío y la fe en la resurrección de Jesús", Revista Católica Internacional 4 (1982) 724-740 (condensado en Selecciones de Teología 22 [1982] 101108 ). 
punto de vista exclusivamente histórico $-\mathrm{y}$ a diferencia de lo que interpretan, ¿por motivos teológicos y apologéticos?, los relatos posteriores de la tumba "vacía" - no hay seguridad "histórica" de que fueran los seguidores de Jesús los que sepultaron su cadáver $^{35}$. Ni hay garantía teológica de que el relato haya que interpretarlo al pie de la letra: de hecho, hoy sabemos que una concepción adecuada de la resurrección de Jesús no exige, como condición de posibilidad, la fe cristiana en la resurrección corporal de Jesús, el hecho de que el cadáver de Jesús hubiera, realmente, desaparecido de la tumba, aunque tampoco se puede excluir que, de hecho, hubiera sido así, pues los textos dejan abierta la cuestión.

Se trata, por tanto, de una cuestión abierta ${ }^{36}$. Los textos biblicos ni postulan necesariamente el hecho histórico de que encontraran realmente la tumba de Jesús y ésta estuviera vacía, ni lo excluyen. Por ello, la respuesta positiva o negativa que los diversos autores dan a la historicidad del hecho no depende tanto de lo que dicen los textos bíblicos en sí mismos, cuanto de la precomprensión de los intérpretes de los mismos $^{37}$. Si se considera como histórico sólo lo que históricamente aparece demostrado, la respuesta a la cuestión de la historicidad será más bien negativa. Si se considera que algo es histórico mientras no exista una duda justificada sobre la credibilidad de las fuentes y testimonios, y se piensa que no puede ser considerado como histórico sólo lo que se puede conocer, por analogía, a partir de los hechos del pasado (y se piensa que el futuro puede mostrarnos cosas muy profundas sobre la realidad, que hoy no nos son aún conscientes), la respuesta, entonces, puede ser más bien positiva.

En todo caso, la cuestión filosófico-dogmática sobre el modo cómo Dios actúa en el mundo ( ¿se pueden dar y se dan de hecho actuaciones milagrosas de Dios en el mundo que "rompen las leyes de la naturaleza" o Dios, por lo que hemos visto hasta ahora, "suele" actuar de otro modo, más en consonancia con las leyes que él ha dado a su creación?) jugará un papel importante en la respuesta que den los autores a la cuestión de si, de hecho, la tumba de Jesús fue encontrada abierta y vacía o bien no fue así.

35. No podemos excluir, desde el punto de vista histórico, con certeza que, en la discusión reciente sobre este tema, se había actualizado la idea de que el cuerpo resucitado no estaba ligado ni cuantitativamente ni cualitativamente a la substancia bioquímica del cuerpo terreno (éste va cambiando continuamente), por lo que el hecho de que la tumba estuviera realmente vacía no era una interpretación como las que encontramos en J. Crossan, Jesís, vida de un campesino judio, Barcelona: Grijalbo, 1994, pp. 450-453, quien sostiene que los cristianos desconocían el lugar de la sepultura. Con anterioridad, ya H. Grass, Ostergeschehen und Osterberichte, Göttingen, 1962, p. 180 ( $c f r$. pp. 173-186) sostenía que los judíos pusieron a Jesús en una tumba común y que sólo más tarde se desarrolló la tradición según la cual lo habría enterrado José de Arimatea.

36. Ya J. Delorme sacaba esta conclusión en "Resurrección y sepulcro de Jesús: Marcos 16,1-8 en la tradición evangélica”, aparecido en P. de Surgy, et ál., La resurrección de Cristo y la exégesis moderna, óp. cit, p. 147.

37. Así H. W. Winden, Wie kam und wie kommt es zum Osterglauben?, Frankfurt, 1982, p. 43. 
Esta es la razón por la cual los investigadores se dividen en este punto y se pueden dar razones tanto a favor como en contra del hecho que las mujeres encontraran realmente vacía la tumba de Jesús. Pues el relato más antiguo, el de Mc 16,1-8, como hemos visto, es muy sobrio y se muestra poco interesado en la comprobación de que la tumba estaba realmente vacía ${ }^{38}$. Es por razones fundamentalmente apologéticas que los evangelistas posteriores irán desarrollando el interés por constatar que la tumba de Jesús estaba realmente vacía (y su "cadáver" no había sido o robado o cambiado de lugar).

Por otro lado, se ha llamado la atención sobre el hecho de que todos los textos ponen a las mujeres como testigos del descubrimiento de la tumba vacía, siendo así que dada la poca "credibilidad" que su testimonio merecía en su entorno cultural, hubiera sido mucho más sencillo y cómodo sustituir su testimonio por el de hombres. Por ello piensan muchos autores que si los primeros cristianos no lo hicieron, ello se debería a que la tradición unánime relacionaba el encuentro de la tumba vacía con María Magdalena (y otras mujeres).

En conjunto, me parece que siguen siendo válidas hoy las conclusiones que sobre este punto sacaba $O$. Oberlinner tras un análisis de los textos del "sepulcro abierto y vacío" 39 .

1) En el testimonio antiguo de la fe pascual fuera de la tradición narrativa de los evangelios, no desempeña ningún papel un sepulcro de Jesús abierto de modo maravilloso y encontrado vacío. La alusión a la antropología judía puede justificar "el sepulcro vacío" como una consecuencia que viene dada con la fe en la resurrección ${ }^{40}$, pero no puede explicar, sin embargo, el "hecho" de un sepulcro abierto y vacío.

38. Esta era ya la tesis de X. Léon-Dufour, Resurrección de Jesús y mensaje pascual, Salamanca, 1973, pp. 163-185. También J. Kremer en su obra Die Osterevangelien: Geschichten um Geschichte, Stuttgart, 1977, p. 17 ( $c$ fr también p. 49, donde indica que hay serios defensores del mensaje pascual que piensan que la tumba no estaba vacía), señala que la constatación de que el sepulcro vacío era sólo un "signo" y no una "prueba" del mensaje pascual, "había sido facilitada por el hecho de presuposición ineludible para que pudiera existir un cuerpo glorificado". Y A. Vögtle (cfr. óp. cit., pp. 97 y s.) es aún más explícito cuando señala que, desde el punto de vista histórico, de la afirmación que la tumba de Jesús fue encontrada vacía se siguen más dificultades que si se presupone lo contrario.

39. O. Oberlinner, "Die Verkündigung der Auferweckung Jesu im geöffneten und leeren Grab", Zeitschrift für die Neutestamentliche Wissenschaft 73 (1982) 159-182.

40. De todos modos quisiera notar que no se trata de una consecuencia necesaria, como ha mostrado H. C. Cavallin, Life after Death. Paul's Argument for the Resurrection of the Dead in 1 Cor 15. Part I: An Enquiry into the Jewish Background, Lund, 1974, pues en el judaísmo de aquel tiempo no se encuentra una única concepción sobre la resurrección de los muertos que exija la desaparición del cadáver para que se pueda hablar de la resurrección de un muerto (y Pablo en 1 Corintios 15 parece presuponer que no es así). 
2) No se puede postular como presupuesto para la posibilidad de la predicación de la resurrección que en Jerusalén hubiera un sepulcro de Jesús conocido realmente como abierto y vacío (no es seguro que inmediatamente después de la muerte de Jesús se contara en Jerusalén el relato de la tumba vacía).

3) La apertura del sepulcro y la constatación de que estaba vacío están, como muestra Mc 16,1-8, al servicio de la predicación del mensaje pascual por parte del ángel; no son su presupuesto, sino la consecuencia de su enlace narrativo con la tumba de Jesús.

4) El análisis a fondo de este conjunto de cuestiones viene a confirmar, en suma, la afirmación de A. Vögtle de que hay que dudar de "si el sepulcro de Jesús poco después del Viernes Santo realmente estaba - yo no digo, bien entendido, vacío, sino- abierto y, por la razón que sea, fue encontrado vacío"'l1.

Por otro lado, como ya he indicado antes, no era necesario en la Jerusalén de la primera comunidad cristiana que la tumba estuviera vacía para que se pudiera hablar de la resurrección de Jesús y se originara la fe pascual (aunque si se hubiera encontrado su cadáver hubiera resultado difícil formular su experiencia pascual como la formularon). $\mathrm{Y}$, en todo caso, los relatos de la tumba vacía (relativamente tardíos: Pablo en 1 Co 15,4 no habla de ella) ni pretenden ni pueden ser una prueba de la resurrección de Jesús. La fe pascual se originó, por lo que parecen indicar los textos más antiguos, a partir de las apariciones del Resucitado y no por el encuentro de la tumba vacía.

\subsection{Los relatos de las apariciones}

Los relatos de apariciones que encontramos en los cuatro Evangelios no nos aportan mucho, según la mayoría de biblistas actuales, para poder saber qué ocurrió "históricamente" en las denominadas "apariciones" pascuales a los primeros testigos. Pues en su texto actual son catequesis relativamente tardias (su publicación en los evangelios hay que situarla a partir de los años 80 , aunque sin duda recogen tradiciones anteriores) que iban dirigidas a los cristianos de la segunda o tercera generación. En cuanto tales, los relatos no permiten sacar, sin más, conclusiones sobre las experiencias primitivas de las apariciones de Jesús (como la aparición de tres hombres a Abraham en Génesis 18 no permite sacar conclusiones sobre la corporeidad de Dios) ${ }^{42}$. Pues lo que se proponen es ayudar

41. Y cita A. Vögtle y R. Pesch, Wie kam es zum Osterglauben, óp. cit., p. 9. En cambio, U. Wilckens toma una postura distinta; cfr. La resurrección de Jesús, óp. cit., pp. 139-144.

42. Así Myre, "La résurrection selon le "Catéchisme de l’Église Catholique", óp. cit., p. 329. Por otro lado, los textos explican el desarrollo de la fe pascual desde sus inicios en 
a las respectivas comunidades a profundizar en el significado fundamental y teológico que la resurrección de Jesús sigue teniendo para ellas ${ }^{43}$.

De todos modos quisiera subrayar aquí que en todos estos relatos se encuentra subyacente lo que descubrimos de fundamental en el modo como Pablo contaba su experiencia pascual: a) hay una iniciativa gratuita y sorprendente de Dios/Cristo que se revela como y cuando quiere a sus testigos, la cual b) comporta un cambio, una conversión radical por parte de los testigos y c) una misión de cara a los demás.

Por otro lado, todos los relatos ( $c f r$. Mt 28,16-20; Lc 24,13-49; In 20,19$21,23)$ subrayan que el Jesús que se presenta es el mismo con el cual ellos convivieron en Galilea y acabó muriendo en una cruz. Pero acentúan también que no es lo mismo (se le conoce y no se le conoce; parece que se le puede tocar, pero pasa a través de puertas cerradas; provoca la fe, pero se puede dudar, etc.).

En todo caso, y esto es lo que se subraya en los cuatro evangelios, lo que hacen los testigos no es contar realmente lo que "vieron", sino narrar la vida concreta, no manipulable de Jesús de Nazaret. Pero, como indiqué antes, lo hacen ahora desde la perspectiva pascual que les abrió los ojos para comprender en profundidad el significado de Jesús, el Hijo de Dios.

Después de lo que acabamos de ver, se comprende que algunos representantes de la exégesis bíblica cuestionen, de modo regular, la "realidad (histórica)" no solo de la tumba vacía, sino también de las apariciones pascuales. Pues "el realismo de las apariciones de Cristo resucitado es de otro orden que el de nuestras percepciones habituales" 4 . Pero su modo de hablar no siempre es fácil de comprender $y$, de hecho, se ha prestado a menudo al equívoco o por lo menos a interpretaciones inadecuadas de su pensamiento. Sobre todo cuando se califica de "objetivas" o de "subjetivas" las apariciones del resucitado a los discípulos. Ya lo hacía notar Delorme ${ }^{45}$ :

Por otro lado, el juego particular de la oposición visible-invisible en los textos nos advierte que también nosotros hemos de tomar las debidas precauciones con nuestras propias palabras. Por ejemplo, cuando oponemos

la Palestina de lengua aramea hasta su inculturación en el mundo helenista. Cfr. también Schmitt, Dictionnaire de la Bible, Supplement IV, col. 488

43. Cfr. Léon-Dufour, óp. cit., pp. 135-161; J. Delorme, "La resurrección de Jesús en el lenguaje del Nuevo Testamento", óp. cit, pp. 146-151 (donde explica el significado de los esquemas visuales y auditivos que utilizan sobre todo Lucas y Juan); y J. Kremer, "El testimonio de la resurrección de Cristo en forma de narraciones históricas", Selecciones de Teología 28 (1989) 323-329.

44. P. Grelot, "Résurrection et immortalité", óp. cit., p. 583.

45. J. Delorme, "La resurrección de Jesús en el lenguaje del Nuevo Testamento", óp. cit., p. 156. 
objetivo-subjetivo a propósito de las apariciones, hay que tener cuidado con la exterioridad que afecta ordinariamente nuestro lenguaje a la pareja sujeto objeto. Tenemos delante el cuarto evangelio para recordarnos que Jesús podía ser percibido como exterior, a pesar de ser totalmente interior a los discípulos. Irreductible a la visión de un objeto exterior, la manifestación del resucitado puede llamarse "objetiva", en cuanto que la iniciativa procede de él, y no de los vivientes. Utilizamos de buena gana la imagen del encuentro, que evoca una experiencia subjetiva y objetiva a la vez, personal y al mismo tiempo interpersonal. Pero esta imagen está pidiendo una trasposición. No se le encuentra a Jesucristo como a un amigo por la calle. El encuentro vivido entre los hombres no está hecho a la medida de una relación que se mantiene con un ser libre de las ataduras del tiempo y del espacio.

En un sentido semejante hacía notar G. Lohfink ${ }^{46}$ algo que me parece muy importante:

Desde la Ilustración hay dos posiciones encontradas: la que afirma el carácter puramente natural de estos fenómenos [se refiere a las apariciones] y la que defiende el carácter sobrenatural de las mismas, hablando de una intervención de Dios en la historia.

Esta alternativa natural-sobrenatural es infeliz, falsa y debería estar teológicamente superada. Cuando Dios actúa en el hombre lo hace en una estructura dialogal. De ahí que una auténtica visión sea a la vez obra de Dios y obra del hombre.

Toda visión auténtica es totalmente obra del hombre y simultáneamente puede ser obra de Dios, que utiliza la fuerza imaginativa del hombre para revelarse en medio de la historia. De todos modos no sería correcto interpretar las apariciones pascuales como imaginaciones psicógenas que Dios simplemente se limitó a orientar para que las imágenes producidas inconscientemente acertaran con la realidad del resucitado. Más bien hay que tomar en serio la causalidad de Cristo resucitado y glorificado, revelado por Dios desde su propia dimensión. Solo esta revelación, que el NT llama aparición, puede ser captada por el hombre, si bien lo es a través de su imaginación psicógena.

Todo esto no es más que aplicar a los fenómenos pascuales de visión la doctrina de la gracia: obra de Dios y obra del hombre. Teológicamente las experiencias de pascua son realmente apariciones del resucitado. Psicológicamente son, al mismo tiempo, visiones debidas a la capacidad imaginativa de los discípulos. Ambas cosas no se excluyen mutuamente.

46. G. Lohfink, "El desarrollo de los acontecimientos pascuales y los comienzos de la comunidad primitiva", Selecciones de Teología 21 (1982) 20. 


\section{La resurrección de Jesús, fuente de esperanza en un mundo injusto}

¿En qué me baso, pues, para mi tesis de que la resurrección de Jesús es fuente de esperanza en un mundo injusto?

Reflexionando sobre el significado de la resurrección de Jesús, Sobrino saca una consecuencia importante ${ }^{47}$ : "Dios ha resucitado a quien, por haber vivido de una determinada manera, había sido crucificado. En una palabra, Dios ha resucitado a un justo e inocente y, por ello, a una víctima. La resurrección de Jesús, pues, no es solo símbolo de la omnipotencia absoluta de Dios - como si Dios hubiese decidido arbitrariamente, sin conexión con la vida y el destino de Jesús, mostrar su omnipotencia y revelarse así como Dios - , sino que es presentada como la defensa que hace Dios de la vida del justo y de las víctimas". Por eso se puede afirmar que la resurrección de Jesús es una Buena Noticia para las víctimas $^{48}$. Y la garantía de que Dios hará justicia.

No es, por ello, casual que un libro escrito para dar esperanza a las víctimas de la marginación y persecución del Imperio romano - me refiero al Apocalipsis - y animar a las Iglesias cristianas a resistir frente a los falsos valores del Imperio $^{49}$, esté todo él marcado por la fe en la resurrección de Jesús. Una resurrección que es vista como la respuesta de Dios a la cruz de Jesús. Por ello se habla del Cordero degollado de pie (es decir, resucitado) ante el trono de Dios ( $c f r$. Ap $1,5-7.17-18 ; 2,8 ; 5,5-6.9-10 ; 14,1)$. En su triunfo sobre los verdugos y sobre la muerte, el Resucitado se convierte, no solo en garantía de resurrección ( cfr Ap 6,9; 7,9-17), sino también en promesa de justicia para los que han sido "degollados por anunciar la palabra de Dios y por haber dado el testimonio debido" (Ap 6,9; cfr. 6,10-11). Una justicia salvadora que no se reserva solo para el cielo nuevo y la tierra nueva. La historia misma revela - y es una ley teológica que se descubre en la historia-, según señala el Apocalipsis, que el Dios del Éxodo, el Dios de Jesús, pide cuentas a todos los imperios del sufrimiento que han provocado en

47. J. Sobrino, en "La Pascua de Jesús y la revelación de Dios desde la perspectiva de las víctimas", óp. cit., p. 207.

48. Según Sobrino, ibíd., p. 212, "si Dios estuvo en la cruz de Jesús, si compartió de ese modo los horrores de la historia, entonces es que se ha consumado la cercanía de Dios a los hombres, iniciada en la encarnación y anunciada y presentizada por Jesús durante su vida terrena. Entonces su acción en la resurrección no es la de un Deus ex machina, sino que expresa las posibilidades intrínsecas de Dios y hace que la omnipotencia que aparece en la resurrección sea creíble - cosa importante, al menos para los crucificados, que desconfían de todo poder que venga de arriba sin haber pasado de alguna manera por la prueba de estar abajo" -

49. Cfr. X. Alegre, "El Apocalipsis, memoria subversiva y fuente de esperanza para los pueblos crucificados", Revista Latinoamericana de Teología 9 (1992) 201-230 y 293 324 (también en Memoria subversiva y esperanza para los pueblos crucificados, óp. cit, pp. 25-86. 
sus víctimas inocentes. Por lo que "no puede haber mal (imperio) que cien años dure".

No quiero decir con ello que la resurrección de Jesús sólo sea Buena Noticia para las víctimas, para los mártires, y no tenga un significado fundamental para todo el mundo. Pues contiene una gran dosis de esperanza. Pero una esperanza accesible solo a los que optan por la justicia. Según Pagola ${ }^{50}$,

...ésta es la gran esperanza del creyente: Todos aquellos que luchen por ser cada día más hombres, un día lo serán. Todos aquellos que trabajen por construir un mundo más humano y justo, un día lo disfrutarán. Todos los que, de alguna manera, hayan creído en el resucitado y hayan vivido, aun sin saberlo, con su espíritu, un día sabrán por fin lo que es VIVIR.

Lo mismo subraya Castillo ${ }^{51}$, a propósito de Juan 8,51 ("los que guardan mi palabra no verán la muerte"), al responder a la pregunta sobre lo que esto implica:

Ante todo, nos viene a decir que nuestra vida no está condenada al fracaso y la frustración, sino que, por el contrario, quienes creemos en Jesús tenemos, por eso mismo, asegurada la pervivencia, por encima de la aplastante evidencia de la muerte. Por lo tanto, nos viene a decir que allí 'donde se estrellan todas las esperanzas humanas' (J. Moltmann), allí precisamente empieza la esperanza de los creyentes. $\mathrm{Y}$, por consiguiente, nos viene a decir que no hay fracaso ni frustración que nos pueda hundir, por muy sombrío que se presente el horizonte, incluso cuando tenemos delante una cosa tan inevitable como es la muerte o una realidad tan aplastante como el fracaso de un condenado a la más humillante de las ejecuciones.

[...] Lo absurdo sería esperar contra la muerte, pero no soportar la contradicción de todo lo que es menos que la muerte. Es más, todo esto nos indica también que la esperanza cristiana no consiste en eliminar la contradicción. Porque no consiste en eliminar la muerte. Pues lo mismo en todo lo demás. En los fracasos de la vida, en las contradicciones grandes y pequeñas, en la oposición que con frecuencia experimentamos de la manera que sea. Con tal, claro está, que se cumpla una condición: que se trate de fracasos, frustraciones y oposición al reino de Dios, al proyecto de Jesús sobre la historia y la humanidad. Por eso, en la medida en que nuestras aspiraciones coinciden con ese proyecto, no tenemos derecho al desaliento y menos aún a la falta de esperanza.

Pues, como señala Pagola,

50. J. A. Pagola, “"El Señor ha resucitado"”, óp. cit., p. 176.

51. J. M. Castillo, óp. cit., p. 214. 
Entramos en la dinámica de la resurrección cuando, enraizados en Cristo, vamos liberando en nosotros las fuerzas de la vida, luchando contra todo lo que nos deshumaniza, nos bloquea y nos mata como hombres y como creyentes.

Vivir la dinámica de la resurrección es vivir creciendo. Acrecentando nuestra capacidad creativa, intensificando nuestro amor, generando vida, estimulando nuestras posibilidades, abriéndonos con confianza al futuro, orientando nuestra existencia por los caminos de la entrega generosa, el amor fecundo, la solidaridad generosa de justicia.

Se trata de entender y vivir la existencia cristiana como 'un proceso de resurrección', superando cobardías, perezas, desgastes y cansancios que nos podrían encerrar en la muerte e instalarnos en un egoísmo estéril y decadente, en una utilización parasitaria de los otros o en una indiferencia y apatía total ante la vida.

En el corazón de este proceso, y como germen permanente de vida y resurrección, está siempre el amor. Él es el signo más sólido de que vivimos "resucitando". "Sabemos que hemos pasado de la muerte a la vida porque amamos a los hermanos. Quien no ama permanece en la muerte" (1 Jn 3,14). ${ }^{52}$

O, como señala Sobrino ${ }^{53}$, "lo específico de la resurrección de Jesús no es, pues, lo que Dios hace con un cadáver, sino lo que hace con una víctima. La resurrección de Jesús muestra en directo el triunfo de la justicia de Dios, no simplemente su omnipotencia, y se convierte en buena noticia para las víctimas: por una vez la justicia ha triunfado sobre la injusticia. En las conocidas palabras de Max Horkheimer, se ha cumplido el anhelo de lo totalmente otro, que "el verdugo no triunfe sobre la víctima'. Dios es el Dios liberador de las víctimas”.

La resurrección de Jesús abre, pues, un horizonte nuevo, universal, para toda la humanidad. Pero, como es obvio, son precisamente los pobres, los oprimidos, los excluidos del sistema, las víctimas, por tanto, de la injusticia que configura el modelo de globalización que domina nuestro mundo, los destinatarios prioritarios de la Buena Noticia de la resurrección de Jesús. Pues ellos, más que nadie, fundamentan su esperanza en la resurrección del Crucificado. Y gracias al testimonio del Nuevo Testamento saben, pueden confiar en que el Dios fiel de la Alianza, el Dios que resucitó a esta gran víctima inocente, que fue Jesús, dándole la razón frente a sus verdugos, también vindicará su justicia, les resucitará y les hará participar en el cielo nuevo y en la tierra nueva que están al llegar.

52. J. A. Pagola, "Resucitar lo muerto. La experiencia pascual como nueva posibilidad de vida", Sal Terrae 76 (1988) 183.

53. J. Sobrino, La fe en Jesucristo, óp. cit, p. 130. 
Y acabo este recorrido a través de la Biblia y de la teología contemporánea con un último texto de Julio Lois ${ }^{54}$, que señala de modo muy claro cuáles son las implicaciones que tiene la resurrección de Jesús para la concepción cristiana de Dios:

La resurrección, al ser considerada en relación con toda la vida de Jesús concluida en la cruz - que con ella queda totalmente validada -, nos presenta el rostro de un Dios con estas características fundamentales:

- Un Dios de vida, vencedor definitivo de la muerte. "Tiene poder sobre la nada (es creador) y poder sobre la muerte (es resucitador)" ${ }^{\prime 55}$.

- Un Dios justo, que está contra la injusticia y que por ello reivindica la suerte de todas las víctimas que a lo largo de la historia no han sido respetadas en su dignidad de persona, a todos los injustamente crucificados.

- Un Dios en lucha contra los ídolos de la muerte y que, en consecuencia, entra en conflictividad con todos los verdugos que son servidores de tales ídolos.

- Un Dios padre y madre, amor radical y misericordioso, perdón sin límites, que declara bienaventurados a los pobres, que acoge a los pecadores y a todos los "don nadie", que se identifica con los marginados, al que es preciso conocer acercándose o haciéndose prójimo de los que están tirados en las cunetas de la historia.

- Un Dios que permanece misterio, siendo un Dios mayor, absolutamente Otro, capaz de otorgarnos salvación definitiva y, al mismo tiempo, un Dios menor, capaz de sufrir con nosotros. Un Dios al que hay que dejar en todo momento ser Dios para así entregarse confiadamente a Él por medio de la fe.

Después de todo lo que acabamos de ver, creo que ahora podemos comprender mejor y valorar adecuadamente la afirmación de Pablo en la Primera carta a los Corintios: "Si Cristo no ha resucitado, tanto mi anuncio como vuestra fe carece de sentido" $(15,14)$.

54. J. Lois, óp. cit., p. 84.

55. Cfr X. Pikaza, La resurrección, Madrid: Biblia y Fe, 1992, p. 11. 